\title{
Why did UK manufacturing productivity growth slow down in the 1970 s and speed up in the 1980s?
}

\author{
Gavin Cameron \\ Nuffield College, Oxford
}

August 1999

\begin{abstract}
After a dramatic slowdown in the 1970s, productivity growth in UK manufacturing in the 1980s returned to something like its pre-slowdown trend. This paper constructs a quarterly dynamic model of TFP growth in UK manufacturing using cointegration techniques, correcting for a variety of measurement biases. The elasticity of output with respect to $R \& D$ capital is estimated at between 0.2 and 0.3 , with human capital also playing a positive and significant role. The paper also determines how much of the UK productivity slowdown in the 1970s was due to the mis-measurement of output and the business cycle and how much was due to structural changes. The answer appears to be about half and half.
\end{abstract}

Keywords: Innovation, Human Capital, Economic Growth, Total Factor Productivity, Unionization, Cointegration Analysis.

JEL Classifications: C13, C22, O30, O47.

Acknowledgments: This paper is based upon Chapter 3 of my D.Phil. thesis at the University of Oxford and was funded by ESRC grant number R000237500. I am extremely grateful to John Muellbauer for his advice and encouragement. I am also grateful for helpful comments to Christine Greenhalgh, Mary Gregory, Bronwyn Hall, Simon Hall, Jonathan Haskel, David Hendry, Melanie Lansbury, Steve Nickell, Steve Redding, Marianne Sensier, Paul Stoneman, and Jonathan Temple, and to participants at the Royal Economic Society Conference and at seminars at Queen Mary \& Westfield College, the Department of Trade and Industry, and in Oxford for helpful comments. I am also grateful to Brian Bell, Alan Carter of the Department of Trade and Industry, and to Ian Richardson of the Office for National Statistics for help with the data. All errors and omissions are my own. 


\section{Introduction}

Growth of total factor productivity slowed in all industrial countries in the 1970s. There is still no universal agreement on the causes of the slowdown, except that it was probably not merely a short-term cyclical phenomenon. Well-known explanations range from input price shocks (Bruno and Sachs, 1985); the growing importance of services (Griliches, 1994, see Sichel, 1997, for an opposing view); lower capital investment (Hamilton and Monteagudo, 1998); vintage capital effects (Wolff, 1996); to the exhaustion of catch-up possibilities (Maddison, 1994). Manufacturing growth increased in the industrial countries in the 1980s, but it was in the UK that the most dramatic increase in the growth rate occurred. For example, Muellbauer (1991) estimated that the annual trend rate of TFP growth in UK manufacturing fell from about 3 per cent in the 1960s to around 1 per cent between 1973 and 1980 , before rising to around $3 \frac{1}{2} 2$ per cent in the 1980 s.

Explanations of the performance of UK productivity can be divided into two broad groups. The first set argues that the slowdown and speed-up were largely a result of mismeasurement. This arises for a number of reasons. First, capital scrapping in 1979-80 meant that from 1981 onwards, the proportionate increase in the capital stock would be substantially higher than recorded by official statistics. This would lead to an upward bias in the total factor productivity growth figures. Second, the 1980-1 recession led to a major shake-out of labour that had been mistakenly hoarded during the late 1970s. Third, mismeasurement of output led to an under-estimate of growth in the 1970s and an overestimate in the 1980s. This is the argument of Bruno and Sachs (1985) and Stoneman and Francis (1994) among others. Other potential sources of measurement error, such as aggregation bias and imperfect competition are also discussed below.

While these explanations are plausible, it does not seem likely that they can explain the whole of the slowdown and speed-up. The second set of explanations argues that there were major structural changes in the UK economy. In the 1970s, it is often argued, institutional rigidities, strong trade unions, lax competition policies, corporatist government interventions, and a slowdown in technological advance led to a growth slowdown. In contrast, it is alleged that growth rose in the 1980s because of the weakening of trade-union power, the withdrawal of state subsidies, the shedding of below average labour and capital, increasing subcontracting, the widespread adoption of 'microchip' technologies, and simply 
that UK manufacturing had so much lost ground to catch up on international best-practice. See Muellbauer (1991) and Bean and Crafts (1996) for further discussion.

There are good reasons for believing that profit-seeking R\&D plays an important role in the growth process, following the research of Aghion and Howitt (1992) among others. In a thorough survey, Griliches (1992) suggests that the elasticity of output with respect to $\mathrm{R} \& \mathrm{D}$ is usually found to be between 0.05 and 0.1 , and that the social rate of return to $\mathrm{R} \& \mathrm{D}$ is between 20 and 50 per cent. Recent work by Jones and Williams (1998) and Barro (1999) has suggested that TFP regressions such as those summarized by Griliches can be reconciled with a variety of simple growth models. For example, Jones and Williams develop a model in the spirit of Romer (1990) that allows for four externalities to R\&D. First, standing on shoulders reduces the costs of rival firms because of knowledge leaks and the movement of skilled labour. ${ }^{1}$ Second, even if there are no technological spillovers, surplus appropriability means that the innovator does not appropriate all the social gains unless she can price discriminate perfectly to rival firms and downstream users. ${ }^{2}$ Third, creative destruction means that new ideas make old production processes and products obsolete. $^{3}$ Fourth, stepping on toes occurs because congestion or network externalities arise when the payoffs to the adoption of innovations are substitutes or complements. ${ }^{4}$ In the model of Jones and Williams, TFP regressions produce an under-estimate of the true social return to $R \& D$ with a maximum downward bias equal to the rate of growth of output. Bartelsman et al. (1998) apply the Williams and Jones framework to firm-level data on Dutch manufacturing and conclude that the private rate of return probably underestimates social returns by only a few percentage points. ${ }^{5}$

As well as investment in knowledge creation, investment in human capital may play an important role in the growth process (see Lucas, 1988). A substantial number of empirical studies have provided supporting evidence. Many of these studies have used the school enrolment ratio (see Barro, 1991), or vocational qualifications as measures of human capital (O’Mahony \& Wagner, 1996, and Jenkins, 1995). Between 1970 and 1992, the ratio of non-manual to manual workers in UK manufacturing rose from 25.6 per cent to 32.9 per cent. Machin (1994) presents evidence that the shift from manual workers to non-manuals is closely paralleled by a shift from unskilled to skilled workers. The reasons for this shift are complex (see Nickell and Bell, 1996, and Haskel, 1999, for discussion). Krugman (1994) argues that it is the result of skills-biased technological change, while Woods (1994) 
argues that it is the result of competition from developing countries. Whatever the cause of the skills shift, it does seem likely that increases in the skills ratio will be associated with either higher TFP or faster growth of TFP (see Benhabib and Spiegel, 1994, for a discussion). Data on skilled and unskilled labour are not available for the entire sample period considered in this paper, so data on the ratio of non-manual to total workers are used as a proxy for the skills ratio. ${ }^{6}$

There has been a significant change in the industrial relations climate in UK manufacturing over the last twenty years. From a position of considerable and increasing strength in the 1970s, the power of unions was severely eroded during the 1980s. One measure of the influence of unions is provided by the New Earnings Survey - the proportion of adult male manual workers covered by some form of collective bargaining agreement. ${ }^{7}$ However, since non-manual workers are less unionized, it is necessary to adjust the proportion of manual males covered by agreements by the proportion of manual males in the total workforce. In 1973, 62.3 per cent of all manufacturing workers were covered by such agreements. $^{8}$ By 1989, that proportion had fallen to 45.8 per cent, with most of the fall occurring in the 1980s. There is a number of reasons to believe that union power will have a significant influence on the performance of firms, and hence on the economy as a whole. Grout (1984) and Ulph and Ulph (1994) all provide theoretical arguments that suggest unions will affect investment, employment, and innovation. Empirical support for these theories has been provided by Machin and Wadhwani (1991), as well as Bean and Crafts (1996) who find that unionization has a negative effect on productivity growth. Purcell (1991) argues that the weakening of union power, especially collective bargaining, significantly weakened the constraints to management action, while Gregg et al. (1993) argue that a change in union status acts as a signal to workers of greater assertiveness on the part of management.

This paper takes a rigorous approach to the measurement issues. It discusses the sources of measurement bias extensively and estimates their effect econometrically. At the same time it also estimates the effect of $\mathrm{R} \& \mathrm{D}$, unionization, and human capital on TFP growth. This allows it to estimate the raw rate of growth of TFP and the rate of growth adjusted for mismeasurement and the business cycle, as well as the effect of the structural variables. 
This paper is divided into four sections. The first discusses measurement issues and describes the data. The second presents the econometric results. The third calculates various decompositions of UK TFP growth. The fourth draws conclusions. A data appendix describes the sources and methods used in the construction of the data-set. A further appendix describes the results of some Johansen (1988) type modelling.

\section{Measurement Issues and Data Description \\ 1.1 The Measurement of Output}

There are two principal problems in the construction of aggregate output data. First, there is the problem of aggregation bias; this arises because the index of aggregate output may not be invariant to changes in the shares of output produced by the individual sectors that compose the index. Second, there is the problem of how to measure output itself; this arises because of differences in the way aggregate output data are collected and the economic concept they attempt to measure. ${ }^{9}$

Aggregation problems arise because different sectors and different firms have different shares in total inputs. A bias arises in the estimate of total factor productivity if deviations in sectoral rates of change are not distributed independently from sectoral shares of total inputs. This is most likely to occur when productivity growth is driven by switches from low productivity and low productivity growth sectors to those with high productivity and high productivity growth, rather than by balanced growth in all sectors. Cameron, Proudman and Redding (1998) produce estimates of the aggregation bias in UK manufacturing TFP growth between 1970 and 1992, and argue that it accounts for around 10 per cent of measured TFP growth, and that most of this occurs after 1987.

Even if there are no aggregation problems, there are likely to be biases in the UK measure of real value-added in manufacturing. An ideal measure of TFP would be derived from a gross output and subtract capital, labour, and intermediate inputs, appropriately weighted. Unfortunately, such a measure for the UK cannot be calculated before 1974, so this paper uses a value-added concept of TFP with capital and labour as inputs. A number of problems must be addressed. First, a Single deflation bias arises because value-added is deflated by the gross output deflator, rather than gross output being deflated by the gross 
output deflator and inputs being deflated by an input deflator (see Stoneman and Francis, 1994). ${ }^{10}$ Second, a Domestic price bias arises because the official producer price (output) index is for home sales only. ${ }^{11}$ Third, a List price bias arises because although the official producer price (output) index is supposed to measure transactions prices, it is unlikely fully to capture the effect of discounting. ${ }^{12}$

This paper uses the index of production of manufacturing output as a measure of output since it is available on a quarterly basis from 1948 onwards, and corrects for these measurement biases by econometric estimation. ${ }^{13}$ The regressions include two variables to allow for the bias: the ratio of input prices to home sales prices and the ratio of import prices to home sales prices. The input price ratio is expected to have a negative sign, while the sign of the import price ratio is ambiguous since the input price ratio contains some foreign import price data as well as reflecting part of the list price bias. ${ }^{14}$ Mendis and Muellbauer (1984) find a negative effect of the input price ratio and a positive effect of the import price ratio in a similar production function based on the index of production.

A further bias in the measurement of output arises because of the effect of price controls. As Darby (1984) argued for the US, and Mendis and Muellbauer (1984) argued for the UK, the price controls that existed in both countries in the 1970s may have led to the misreporting of price rises. Firms had incentives to claim spurious quality improvements or to re-label goods in order to be allowed to increase prices. The official producer prices (output) index therefore understates the true rise in prices, and therefore the rise in real output is overstated. In Britain, price controls were introduced in April 1973, slightly relaxed in December 1974 and August 1976, and replaced by the much weaker Price Code in August 1977. The Price Commission, which implemented these controls, was abolished in 1979. Mendis and Muellbauer (1984) construct a index of the effect of the price

controls, based on the assumption that the more intense the controls, the greater the bias to the price index due to evasion. This paper uses the Mendis and Muellbauer measure of the price control bias.

\subsection{Measurement of Inputs}

It is well known that labour utilization varies over the business cycle. However, since firms that under-utilize labour usually still pay their workers for a normal week, under-utilization 
cannot be observed directly. Muellbauer (1984) proposes a method of deducing the average utilization rate from shifts in the upper tail of the distribution of utilisation using data on overtime hours. He suggests the use as regressors of the inverse of the ratio of overtime hours to total hours, and an interaction between normal hours worked and overtime hours (see the data appendix for full details). The inverse of the overtime hours variable should have a negative coefficient while the normal and overtime hours interaction should have a positive coefficient. This allows the effect of utilization to be estimated directly by including cyclical terms in the estimation.

There are two main issues in the measurement of the capital stock. The first is whether it should be adjusted for cyclical utilization. The second is whether the gross stock data are correct. Denison (1974), among others, has suggested that it is not appropriate to adjust capital for cyclical utilization. Muellbauer (1984) suggests that ostensible measures of capital utilization, such as those in the CBI Industrial Trends Survey, may be as much a measure of labour utilization as of capital utilization. UK gross capital stock data are constructed from gross investment data under fixed service life assumptions. The assumed service lives do not vary cyclically or respond to relative factor prices. When companies become bankrupt and assets are sold abroad or simply taken out of use, no allowance is made for such scrapping. These assumptions are difficult to reconcile with the economic responses that would be expected when prices, wages, taxes and demand vary. The approach taken by Muellbauer (1991) is to fit time trends with linear splines allowing slope changes to occur at times when, on a priori grounds, one would expect a great deal of unobserved scrapping.

In summary, there is a number of different ways of looking at the inclusion of the cyclical terms in our regressions. The first justification is that they act to convert what are essentially stock variables (the capital stock and the labour stock) into flow variables, and to correct for the measurement problems caused by differences between paid for hours and actual hours worked (see Muellbauer, 1991). The second justification is that because of the existence of non-linearities and asymmetries in the business cycle, it is necessary to condition on the state of the business cycle to remove non-linearities in macroeconomic time series (see Acemoglu and Scott, 1994, and Sensier, 1998). 


\subsection{Data Description}

Sources of the data series used are provided in the data appendix to this paper. Only a brief description is given here. Figure 1 shows the dependent variable, ltfp (log total factor productivity, corrected for the double-counting of $R \& D$ inputs ${ }^{15}$ ) along with three variables hypothesized to have a major influence on productivity. These are $l R \& D I$ (the log of the stock of industry-funded business enterprise spending on R\&D divided by the physical capital stock), lskill (the log ratio of non-operative to total workers), lunion (the log of the proportion of manual male workers covered by collective agreements multiplied by the proportion of manual males in the workforce). Of most interest are the behaviour of the unionisation variable, which rises sharply in the early 1970s and then collapses in the early $1980 \mathrm{~s}^{16}$, and the R\&D (industry-funded Business Enterprise R\&D) to capital stock ratio which rises quite rapidly in the 1960s, slows down in the 1970s, and then speeds-up in the 1980s. This pattern is quite invariant to the depreciation rate chosen or lag length, and reflects the rapid increase in UK manufacturing's R\&D efforts in the 1960s, the rise of government-funding in the 1970s (not reflected in these figures and sometimes displacing industry-funded R\&D) and the ebb of government-funding in the 1980s (with a compensating increase in industry-funding).

Figure 2 shows the cyclical terms. These are over (the inverse of the ratio of overtime hours worked to total hours worked), normal (the interaction between normal hours and overtime hours), and cap (the log of the CBI capacity utilization index). The over and cap variables show the cyclical nature of manufacturing in the UK with particular peaks (corresponding to cyclical troughs) in the mid 1970s and early 1980s. The early 1990s recession is seen as quite mild by these data. The interaction between normal hours and overtime hours, normal, plays a particular role in the 1960s, reflecting the fall in normal hours and hence an increase in 'normal' or systematic overtime.

Figure 3 shows the bias terms. These consist of $p c$, which is the proxy for price controls in the 1970s; $p r$, which is the ratio of the price of intermediate inputs to price of domestic output in manufacturing; and $p w$, which is the ratio of the price of foreign goods to domestic output in manufacturing. The price control bias, $p c$, is only operative between $1973 q 2$ and 1977q3. The log ratio of input to output prices, $p r$, rises sharply in 1973 and then drifts down, with an especially sharp fall in 1986, followed by further falls. The log ratio of the price of foreign goods to domestic goods, $p w$, also rises sharply in the early 
1970s at the time of the Bretton Woods break-up, and then falls dramatically in the late 1970s as sterling rises in value. The exit of sterling from the ERM is also marked by a rise in the value of $p w$, although a surprisingly small one in the context of earlier movements.

Table 1 reports t-statistics for Augmented Dickey-Fuller tests (see MacKinnon, 1991), along with the corrected critical values for the variables of interest. The hypothesis that the variables are not $I(0)$ cannot be rejected. The right-hand column shows the results of ADF tests on the first-differences of the variables, and cannot reject the hypothesis that the variables are all $I(1)$. Having established that all the variables of interest are integrated, the estimation procedure looks for co-integrating relationships, and tests these by using Augmented Dickey-Fuller tests on the generated residuals (see Hendry, 1995, chapter 6).

\section{Table 1}

Augmented Dickey-Fuller Tests

\begin{tabular}{|c|c|c|}
\hline & Test on Level & Test on Difference \\
\hline ltfp & -1.64 & $-4.39 * *$ \\
\hline$p c$ & -2.71 & $-5.60 * *$ \\
\hline$p r$ & -0.92 & $-5.37 * *$ \\
\hline$p w$ & -2.36 & $-4.69 * *$ \\
\hline lunion & -2.48 & $-4.77 * *$ \\
\hline lskill & -2.47 & $-4.14 * *$ \\
\hline IR\&D1 & -2.85 & $-3.98 *$ \\
\hline cap & -3.40 & $-5.17 * *$ \\
\hline over & -3.17 & $-5.93 * *$ \\
\hline normal & -3.30 & $-4.97 * *$ \\
\hline
\end{tabular}

Notes: Critical values: 5\%=-3.442 1\%=-4.025 (from MacKinnon, 1991), Constant and Trend included, sample 1955q1 to 1995q3, except cap which has a sample of $1958 q 3$ to 1995q3. pc is a proxy for price controls in the 1970s; pr is the log ratio of intermediate input prices to output prices; $p w$ is the log ratio of export prices to output prices; lskill is the log ratio of administrative, technical and clerical staff to total workers; lunion is the log of the proportion of full-time manual males covered by collective agreements; $l R \& D 1$ is the log ratio of the stock of industry-funded Business Enterprise spending on $R \& D(B E R D)$ to the physical capital stock; cap is the log of the capacity utilization based on CBI survey data; over is the inverse of the ratio of overtime hours to total hours worked; normal is the ratio of overtime hours to normal hours. Details of the construction of $p c, p r, p w$, cap, over, and normal can be found in the data appendix. 
Figure 1 Dependent Variable and Long-Run Influences on Productivity
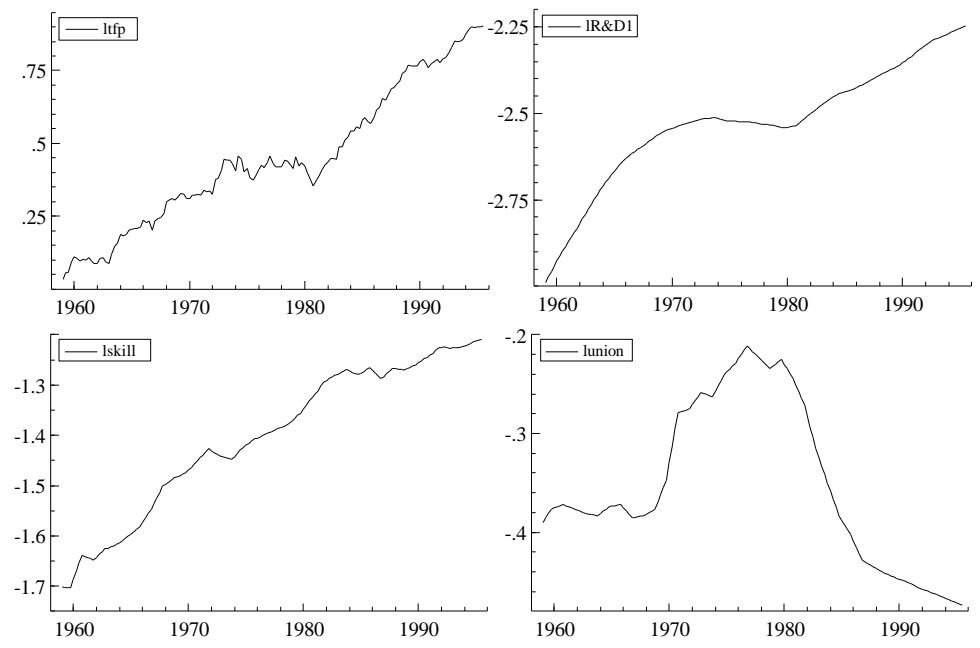

Figure 2 Cyclical Terms
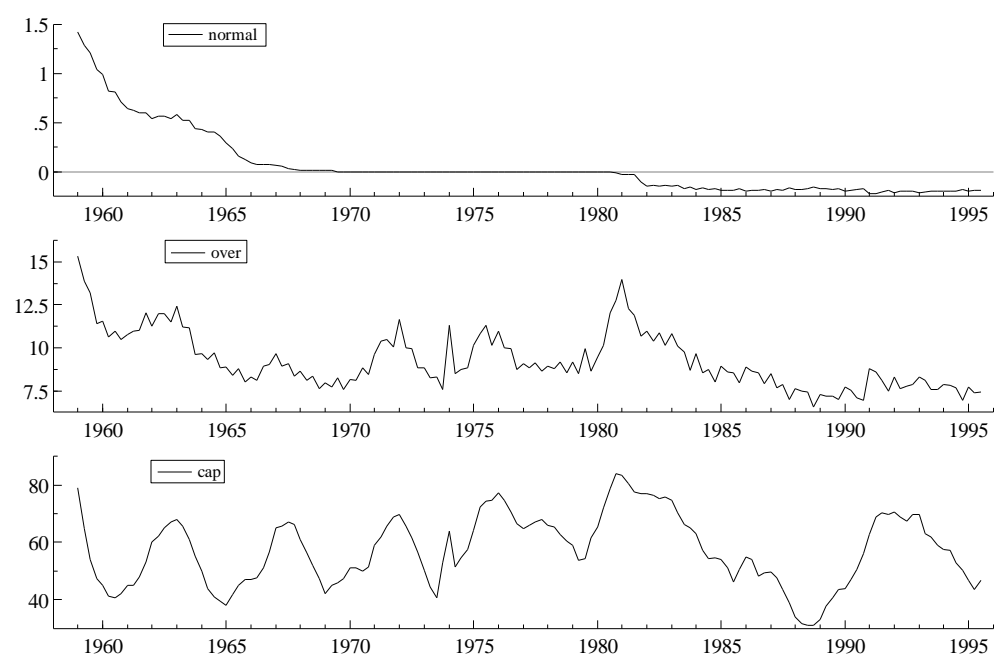

Figure 3 Bias Terms
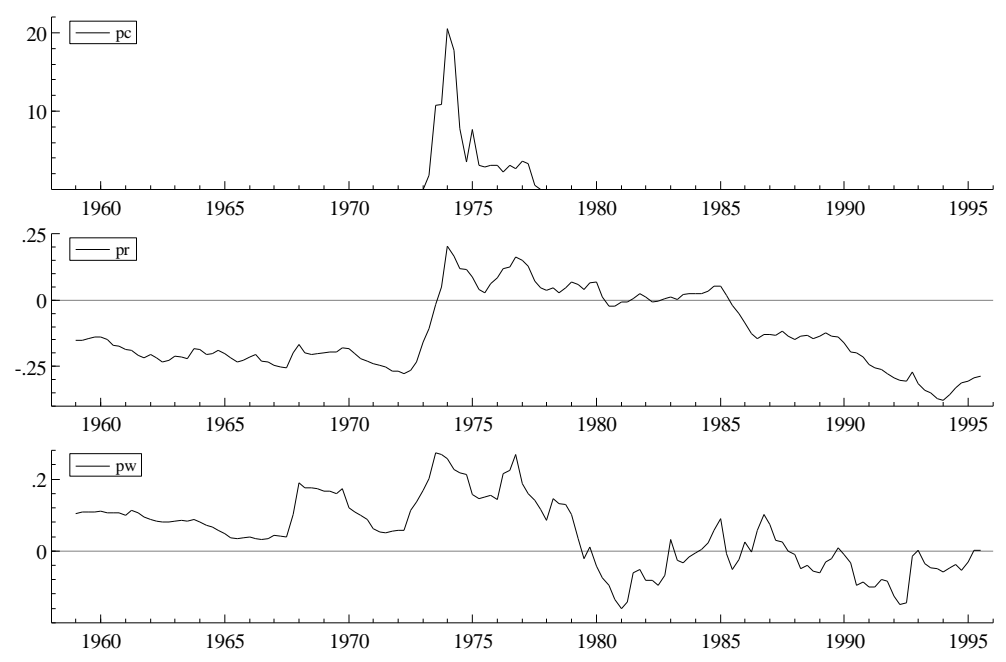
As a first stage in this exercise, a vector autoregressive model was estimated using the Johansen (1988) procedure. For simplicity of estimation and interpretation, the vector of variables considered was restricted to $\{l t f p, l R \& D 1$,lskill,lunion $\}$. In addition to the four stochastic variables, the system contained a constant, a trend, and a split time trend that starts in the first quarter of $1973(\operatorname{tr} 73 q 1)$. The results of this exercise suggested that there was a single cointegrating vector, which could be interpreted as an ltfp equation, since there was no significant feedback from the other equations. See appendix I for the results.

Let us now turn to the modelling of the conditional density of ltfp, given the other variables. ${ }^{17}$ This is equivalent to the assumption that the set of variables $\{l R \& D 1, l$ skill,lunion $\}$ is weakly exogenous for the parameters of the total factor productivity model. Following the earlier discussion, the paper estimates dynamic equations of the following form (although with a richer lag structure):

$$
\operatorname{ltfp}_{\mathrm{t}}=\alpha_{1}+\alpha_{2} \operatorname{ltfp}_{\mathrm{t}-1}+\alpha_{3} \Delta \operatorname{ltfp}_{\mathrm{t}-1}+\phi\left(\mathrm{Z}_{\mathrm{t}-1}\right)+\varphi\left(\Delta \mathrm{Z}_{\mathrm{t}-1}\right)+\varepsilon_{\mathrm{t}}
$$

where the vector $\mathrm{Z}$ includes the three variables from the VAR model $\{l R \& D 1$, lskill,lunion $\}$, as well as the overtime hours, capacity utilisation, price bias terms, and time trend discussed earlier.

Following a General to Specific sequential simplification method (see Hendry, 1995), a parsimonious and congruent model was derived. Table 2 shows the results of four different specifications and reports solved static long-run coefficients and standard errors for four variables of special interest, lskill, lunion, $l R \& D l$ (the ratio of the stock of industry-funded BERD to physical capital), and Trend, and a variety of diagnostic tests. The human capital and $R \& D$ variable each enter the dynamic model with a lag of four quarters, while unionization enters with a lag of two quarters. Each regression also included bias and cyclical terms in $p c, p r, p w$, over, and normal (the variable based on the log of the CBI capacity utilization index, cap, was found to be insignificant), but these are not reported at this stage since they have little impact on the long-run behaviour of the model. All these terms enter only in lags of one quarter or more to rule out any contemporaneous correlation with ltfp. 
Reading across table 2, regression 1 estimates that unionization has a significant and negative effect on TFP and that both the R\&D stock (the log ratio of the stock of industryfunded BERD to the physical capital stock) and the human capital ratio have significant and positive effects on TFP. A 1 per cent increase in the R\&D stock is estimated to raise TFP by 0.29 per cent. A 1 per cent increase in the ratio of administrative, technical, and clerical staff to total workers is estimated to raise TFP by 0.28 per cent. A 1 per cent increase in unionization is estimated to reduce TFP by 0.13 per cent. The diagnostics show that the residuals are stationary and well-behaved. Regressions 2 and 3 show the deletion of, respectively, the human capital variable and then the unionization variable. The deletion of human capital reduces the coefficient on the $R \& D$ stock somewhat and a Likelihood Ratio test $\left(\chi^{2}(1)=4.08[\mathrm{P}=0.04]\right)$ rejects the restriction. The deletion of unionization has little effect on the estimated coefficients and standard errors and the LR test of the joint restriction that unionization and human capital have no effect on total factor productivity is rejected $\left(\chi^{2}(2)=6.18[\mathrm{P}=0.05]\right)$. Regression 4 shows the effect of deleting the $\mathrm{R} \& \mathrm{D}$ stock from the equation, which is to raise the estimated coefficient on the trend compared with regression 1 , and the restriction is rejected $\left(\chi^{2}(1)=4.31[\mathrm{P}=0.04]\right)$.

Table 3 shows the results of four regressions (numbers 5 to 8 ) where the R\&D stock variable is different in each. As before, $l R \& D 1$ is the log ratio of the stock of industryfunded BERD to physical capital. $l R \& D 2$ is the log ratio of the stock of total BERD to physical capital. $l R \& D 3$ is the $\log$ ratio of the stock of technological royalties to physical capital. $I R \& D 4$ is the $\log$ of the stock of industry-funded BERD. Compare regression 5 with regression 1 . The effect of $l R \& D 1$ is smaller and less significant while $l R \& D 3$ enters with a significant and negative coefficient. However, a Likelihood Ratio test $\left(\chi^{2}(1)=2.19\right.$ $[\mathrm{P}=0.14])$, cannot reject the restriction that the coefficient on $l R \& D 3$ is zero at the 5 per cent level. Regression 6 restricts the coefficient on $l R \& D 1$ to be zero in order to check whether the negative coefficient on $l R \& D 3$ is caused by collinearity between $l R \& D 1$ and $l R \& D 3$, but the coefficient on $l R \& D 3$ becomes more negative and slightly more significant. The restriction that the coefficient on $l R \& D l$ is zero is rejected $\left(\chi^{2}(1)=5.54[\mathrm{P}=0.02]\right)$.

Regression 7 replaces $l R \& D 1$ with $l R \& D 2$. The difference between these two variables is that while $l R \& D 1$ represents the stock of industry-funded BERD, $l R \& D 2$ represents the stock of total BERD, regardless of its source of funding. It is often argued (see Griliches, 1980, for example) that R\&D funded by industry itself is likely to yield higher returns than 
that funded, by, for example, government. The estimated coefficient on $l R \& D 2$, the total BERD stock variable, in regression 7 is slightly smaller than that of $l R \& D 1$, the industryfunded BERD stock, but the difference is not significant.

So far the R\&D variables considered have been stocks of R\&D divided by the physical capital stock. An alternative specification would be to use $l R \& D 4$, which is simply the stock of industry-funded BERD. Regression 8 estimates a slightly smaller coefficient on $l R \& D 4$ than for $l R \& D 1$ in regression 1 , similar effects for unionization and human capital, and a slightly worse equation standard error. The similarity of the two different specifications of $\beta$ suggest that dividing the $R \& D$ stock by physical capital is a good method of normalization, rather than suggesting that one particular specification of $\beta$ is better than another.

A number of specification and parameter stability tests were also conducted, and some are reported in table 4. Cameron and Muellbauer (1996) used split linear splines to capture trend breaks in UK manufacturing TFP. It is interesting to look at the effect of including the trend breaks specified by Cameron and Muellbauer, although the focus of this paper is on the effect of R\&D, unionization, and human capital on TFP. Their model suggests that the main trends breaks in the UK occurred in 1973q1, 1979q3, 1980q4, 1990q3 and 1992q2. These trends breaks occur for a number of reasons, two of the most important being capital scrapping and mis-measurement of the business cycle. In particular, the $1979 q 3$ trend break is likely to represent cyclical mis-measurement in the early 1980s recession, while the 1990q3 and 1992q2 trend breaks represent the early 1990s recession. Regression 9 reports the results of a regression including our variables of interest $\{l s k i l l$, lunion, $I R \& D 1\}$ and the five trend breaks. These trend breaks reduce the explanatory power of our variables of interest and are jointly significant. Regression 10 reports the results of a regression using the trend breaks rather than our variables of interest. Note that the standard error is slightly lower than for regression 1 but that there is evidence of structural mis-specification (the Ramsey RESET test cannot be rejected). The subsequent analysis in the paper uses the specification from regression 1 on the grounds that it contains economic variables, rather than time trends fitted post-hoc.

Regression 11 contains the same variables as regression 1 but adds a time dummy interaction for $l R \& D 1$ which starts in $1973 q 1$. This is an attempt to test whether the return 
to R\&D is different after the British crisis of 1972-1973 than before. The Wald test for the restriction $(\mathrm{F}(1,126)=0.024[\mathrm{P}=0.88])$ cannot reject the restriction that the $l R \& D 1$ coefficient does not vary. No evidence was found of a structural break in the R\&D parameter during any quarter of 1972, 1973 and 1974. Regression 12 reports the results of a similar regression but adds a time dummy interaction for lskill instead. The Wald test for the restriction $(\mathrm{F}(1,126)=0.083[\mathrm{P}=0.77])$ cannot be rejected either. Regression 13 takes a different approach to modelling the trend properties of UK TFP. The shifting time-trends are replaced with an I(2) stochastic time trend as suggested by Harvey (1989). The resulting model fits the data rather worse than regression 1 and has little impact on the estimated effects of $l R \& D 1, l s k i l l$ and lunion, except to raise the coefficient on lskill. A number of parameter stability tests were also conducted. These suggested that the coefficients on $l R \& D 1$, lskill, and lunion are reasonably stable. A typical example is the Chow test (Chow, 1960) for a parameter change in 1973q1, $(\mathrm{F}(15,113)=1.44[\mathrm{P}=0.14])$ which cannot reject the hypothesis of parameter constancy.

Schankerman (1981) has pointed out that the labour and capital components of R\&D are 'double-counted' in total factor productivity regressions, because they appear once in the traditional measures of labour and capital and once again in the research and development expenditure input. This 'Excess Return Interpretation' or ERI means that the calculated elasticity of $R \& D$ is either a risk premium or a supra-normal profit on $R \& D$ investments. Schankerman also notes that another bias occurs because current R\&D spending is usually counted as an expense by firms (the 'expensing bias'), and is therefore treated as an intermediate good in the National Accounts and subtracted from value-added. Schankerman demonstrates that the effect of the excess returns interpretation is to reduce the measured contribution of R\&D to output growth, while the effect of the expensing bias can be to either increase or decrease measured returns to R\&D. All the regressions reported above have been corrected for the double-counting bias, by subtracting $\mathrm{R} \& \mathrm{D}$ labour and R\&D capital from labour and physical capital inputs respectively. In this paper it is not possible to correct for the expensing bias since the measure of output is not exactly value-added, but is based on the index of production. As a test of the robustness, a regression analogous to regression 1 above was run, using a dependent variable not corrected for the double-counting bias. Recall that the coefficient on $l R \& D 1$ in regression 1 was 0.288 with an HCSE of 0.11. The coefficient on $l R \& D 1$ in a regression of the uncorrected dependent variable was 0.311 with an HCSE of 0.12. The uncorrected 
estimate is thus slightly higher, but not significantly so. This confirms Schankerman's argument that double-counting can bias upwards the estimate of the elasticity of output with respect to $R \& D$ capital, but suggests that, empirically, this bias is insignificant. ${ }^{18}$

\section{Table 2}

\section{Solved Static Long Run Estimates}

Sample Period 1959q1 to 1995q3

Dependent Variable is log Total Factor Productivity (corrected for double-counting)

\begin{tabular}{|c|c|c|c|c|}
\hline $\begin{array}{l}\text { Independent } \\
\text { Variables }\end{array}$ & (1) & $\begin{array}{l}\text { Regression Number } \\
\text { (2) }\end{array}$ & (3) & (4) \\
\hline lskill & $\begin{array}{l}0.276 \\
(0.12)\end{array}$ & & & $\begin{array}{l}0.240 \\
(0.15)\end{array}$ \\
\hline IUNION & $\begin{array}{l}-0.127 \\
(0.06)\end{array}$ & $\begin{array}{l}-0.094 \\
(0.06)\end{array}$ & & $\begin{array}{l}-.043 \\
(0.07)\end{array}$ \\
\hline IR\&D1 & $\begin{array}{l}0.288 \\
(0.11)\end{array}$ & $\begin{array}{l}0.227 \\
(0.11)\end{array}$ & $\begin{array}{l}0.210 \\
(0.10)\end{array}$ & \\
\hline Trend & $\begin{array}{l}0.0043 \\
(0.0006) \\
\end{array}$ & $\begin{array}{l}0.0053 \\
(0.0006) \\
\end{array}$ & $\begin{array}{l}0.0056 \\
(0.0003)\end{array}$ & $\begin{array}{l}0.0051 \\
(0.0006) \\
\end{array}$ \\
\hline $\begin{array}{l}\text { S.e. } \\
\mathbf{R}^{2}\end{array}$ & $\begin{array}{l}0.0112 \\
0.9979\end{array}$ & $\begin{array}{l}0.0113 \\
0.9979\end{array}$ & $\begin{array}{l}0.0114 \\
0.9978\end{array}$ & $\begin{array}{l}0.0113 \\
0.9979\end{array}$ \\
\hline ADF (4) & $-4.8[0.01]$ & $-4.5[0.01]$ & $-4.4[0.01]$ & $-4.6[0.01]$ \\
\hline $\operatorname{AR} \mathbf{F}(\mathbf{5}, 123)$ & $0.70[0.62]$ & $1.19[0.32]$ & $1.22[0.30]$ & $0.50 \quad[0.78]$ \\
\hline $\operatorname{ARCH} F(4,120)$ & $1.06[0.38]$ & $1.40[0.24]$ & $1.10[0.36]$ & $0.78 \quad[0.54]$ \\
\hline Normality $\chi^{2}(2)$ & $2.45[0.29]$ & $3.15[0.21]$ & $2.28 \quad[0.32]$ & $1.92[0.38]$ \\
\hline HS F $(33,94)$ & $1.08[0.38]$ & $1.06[0.41]$ & $1.14[0.31]$ & $0.75[0.50]$ \\
\hline RESET F $(1,127)$ & $1.50[0.22]$ & $5.28[0.02]$ & $2.86[0.09]$ & $1.78[0.19]$ \\
\hline
\end{tabular}

Notes:

Heteroscedasticity-Consistent standard errors in normal parentheses. P-values appear in square brackets. All regressions include lagged dependent variable, cyclical terms and bias terms (see text).

SKILL is the ratio of administrative, technical and clerical staff to total workers. UNION is the proportion of full-time manual males covered by collective agreements. $R \& D 1$ is the ratio of the stock of industryfunded Business Enterprise spending on $R \& D(B E R D)$ to the physical capital stock.

$A D F(N)$

$A R(M-N, T-K-M)$

$A R C H(r, T-2 r-K)$

Normality (2)

$H S$

$\operatorname{RESET}(j, T-j-K)$
Augmented Dickey-Fuller test with N lags, MacKinnon (1991).

$F$-test for $N$-th to $M$-th order residual autocorrelation in a model with $K$ regressors and tobservations, Harvey (1989).

F-test for Autoregressive Conditional Heteroscedasticity of $r$-th order, Engle (1982).

$\chi^{2}$ test for Normality, Jarque and Bera (1980).

F-test for heteroscedasticity, White (1980).

F-version of the RESET test for $j$ powers, Ramsey (1969). 


\section{Table 3}

\section{Solved Static Long Run Estimates \\ Sample Period 1959q1 to 1995q3}

Dependent Variable is log Total Factor Productivity (corrected for double-counting)

\begin{tabular}{|c|c|c|c|c|}
\hline $\begin{array}{l}\text { Independent } \\
\text { Variables } \\
\end{array}$ & (5) & $\begin{array}{l}\text { Regression Number } \\
\text { (6) }\end{array}$ & (7) & (8) \\
\hline Iskill & $\begin{array}{l}0.178 \\
(0.16)\end{array}$ & $\begin{array}{l}0.154 \\
(0.18)\end{array}$ & $\begin{array}{l}0.255 \\
(0.16)\end{array}$ & $\begin{array}{l}0.254 \\
(0.20)\end{array}$ \\
\hline IUNION & $\begin{array}{l}-0.164 \\
(0.07)\end{array}$ & $\begin{array}{l}-0.060 \\
(0.06)\end{array}$ & $\begin{array}{l}-0.105 \\
(0.06)\end{array}$ & $\begin{array}{l}-0.090 \\
(0.10)\end{array}$ \\
\hline IR\&D1 & $\begin{array}{l}0.263 \\
(0.11)\end{array}$ & & & \\
\hline IR\&D2 & & & $\begin{array}{l}0.224 \\
(0.13)\end{array}$ & \\
\hline IR\&D3 & $\begin{array}{l}-0.174 \\
(0.09)\end{array}$ & $\begin{array}{l}-0.182 \\
(0.09)\end{array}$ & & \\
\hline IR\&D4 & & & & $\begin{array}{l}0.270 \\
(0.18)\end{array}$ \\
\hline Trend & $\begin{array}{l}0.0066 \\
(0.0009)\end{array}$ & $\begin{array}{l}0.0075 \\
(0.0008)\end{array}$ & $\begin{array}{l}0.0044 \\
(0.0006)\end{array}$ & $\begin{array}{l}0.0061 \\
(0.0008)\end{array}$ \\
\hline $\begin{array}{l}\text { s.e. } \\
\mathbf{R}^{2}\end{array}$ & $\begin{array}{l}0.0106 \\
0.9981\end{array}$ & $\begin{array}{l}0.0108 \\
0.9981\end{array}$ & $\begin{array}{l}0.0111 \\
0.9980\end{array}$ & $\begin{array}{l}0.0112 \\
0.9979\end{array}$ \\
\hline ADF (4) & $-4.9[0.01]$ & $-4.8[0.01]$ & $-4.7[0.01]$ & $-4.7[0.01]$ \\
\hline AR F(5,123) & $0.45[0.81]$ & $0.40[0.85]$ & $0.51[0.77]$ & $0.34[0.89]$ \\
\hline ARCH F(4,120) & $0.69[0.60]$ & $0.45[0.77]$ & $1.22[0.31]$ & $1.06[0.38]$ \\
\hline Normality $\chi^{2}(2)$ & $1.16[0.56]$ & $0.33[0.85]$ & $2.79[0.25]$ & 0.97 [0.62] \\
\hline HS F $(33,94)$ & $1.07[0.39]$ & $1.17[0.28]$ & $1.18[0.27]$ & $1.21[0.24]$ \\
\hline RESET F(1,127) & $2.70[0.10]$ & $1.12[0.29]$ & $0.37[0.54]$ & $0.16[0.69]$ \\
\hline
\end{tabular}

Notes:

Heteroscedasticity-Consistent standard errors in normal parentheses. P-values appear in square brackets. All regressions include lagged dependent variable, cyclical terms and bias terms (see text).

SKILL is the ratio of administrative, technical and clerical staff to total workers. UNION is the proportion of full-time manual males covered by collective agreements. $R \& D 1$ is the ratio of the stock of industryfunded Business Enterprise spending on $R \& D(B E R D)$ to the physical capital stock. $R \& D 2$ is the ratio of the stock of total BERD to the physical capital stock. R\&D3 is the ratio of the stock of technological royalties to the physical capital stock. $R \& D 4$ is the stock of industry-funded BERD.

$A D F(N)$

$A R(M-N, T-K-M)$

$A R C H(r, T-2 r-K)$

Normality (2)

$H S$

$\operatorname{RESET}(j, T-j-K)$
Augmented Dickey-Fuller test with N lags, MacKinnon (1991).

F-test for $N$-th to $M$-th order residual autocorrelation in a model with $\mathrm{K}$ regressors and tobservations, Harvey (1989).

F-test for Autoregressive Conditional Heteroscedasticity of r-th order, Engle (1982).

$\chi^{2}$ test for Normality, Jarque and Bera (1980).

F-test for heteroscedasticity, White (1980).

$F$-version of the RESET test for $j$ powers, Ramsey (1969). 
Table 4

Solved Static Long Run Estimates

Sample Period 1959q1 to 1995q3

Dependent Variable is log Total Factor Productivity (corrected for double-counting)

\begin{tabular}{|c|c|c|c|c|c|}
\hline \multirow{2}{*}{$\begin{array}{l}\text { Independent } \\
\text { Variables }\end{array}$} & \multirow[b]{2}{*}{ (9) } & \multicolumn{2}{|c|}{ Regression Number } & \multirow[b]{2}{*}{ (12) } & \multirow[b]{2}{*}{ (13) } \\
\hline & & (10) & (11) & & \\
\hline lskill & $\begin{array}{l}0.13 \\
(0.14)\end{array}$ & & $\begin{array}{l}0.30 \\
(0.18)\end{array}$ & $\begin{array}{l}0.31 \\
(0.20)\end{array}$ & $\begin{array}{l}\text { STAMP } \\
0.39 \\
(0.15)\end{array}$ \\
\hline IUNION & $\begin{array}{l}-0.11 \\
(0.07)\end{array}$ & & $\begin{array}{l}-0.13 \\
(0.07)\end{array}$ & $\begin{array}{l}-0.13 \\
(0.07)\end{array}$ & $\begin{array}{l}-0.13 \\
(0.08)\end{array}$ \\
\hline IR\&D1 & $\begin{array}{l}0.14 \\
(0.11)\end{array}$ & & $\begin{array}{l}0.29 \\
(0.12)\end{array}$ & $\begin{array}{l}0.29 \\
(0.12)\end{array}$ & $\begin{array}{l}0.27 \\
(0.10)\end{array}$ \\
\hline IR\&D1*D73q1 & & & $\begin{array}{l}-0.002 \\
(0.01)\end{array}$ & & \\
\hline Iskill*D73q1 & & & & $\begin{array}{l}-0.006 \\
(0.02)\end{array}$ & \\
\hline Trend & $\begin{array}{l}0.0078 \\
(0.002)\end{array}$ & $\begin{array}{l}0.0072 \\
(0.002)\end{array}$ & $\begin{array}{l}0.0042 \\
(0.001)\end{array}$ & $\begin{array}{l}0.0041 \\
(0.001)\end{array}$ & \\
\hline Tr73q1 & $\begin{array}{l}-0.0047 \\
(0.003)\end{array}$ & $\begin{array}{l}-0.0042 \\
(0.002)\end{array}$ & & & \\
\hline $\operatorname{Tr} 79 q 3$ & $\begin{array}{l}-0.0053 \\
(0.003)\end{array}$ & $\begin{array}{l}-0.0031 \\
(0.002)\end{array}$ & & & \\
\hline Tr80q4 & $\begin{array}{l}0.0101 \\
(0.003)\end{array}$ & $\begin{array}{l}0.0084 \\
(0.003)\end{array}$ & & & \\
\hline Tren & $\begin{array}{l}-0.0050 \\
(0.005)\end{array}$ & $\begin{array}{l}-0.0058 \\
(0.001)\end{array}$ & & & \\
\hline s.e. & 0.0110 & 0.0110 & 0.0112 & 0.0112 & 0.0132 \\
\hline $\mathbf{R}^{2}$ & 0.9984 & 0.9984 & 0.9979 & 0.9979 & 0.9967 \\
\hline ADF (4) & $-5.3[0.01]$ & $-5.4[0.01]$ & $-4.8[0.01]$ & $-4.8[0.01]$ & \\
\hline AR F $(5,123)$ & $0.63[0.67]$ & $0.66[0.65]$ & $0.73[0.61]$ & $0.75[0.59]$ & \\
\hline ARCH F(4,120) & $1.90[0.12]$ & $1.86[0.12]$ & $1.01[0.41]$ & $0.97[0.43]$ & \\
\hline Normality $\chi^{2}(2)$ & $2.66[0.26]$ & $2.55[0.28]$ & $2.42[0.30]$ & $2.38[0.30]$ & \\
\hline HS F $(33,94)$ & $1.13[0.32]$ & $1.10[0.35]$ & $1.00[0.48]$ & $1.52[0.07]$ & \\
\hline RESET F(1,127) & $3.57[0.06]$ & $4.96[0.03]$ & $1.48[0.23]$ & $1.49[0.22]$ & \\
\hline
\end{tabular}

Notes:

Heteroscedasticity-Consistent standard errors in normal parentheses. P-values appear in square brackets.

All regressions include lagged dependent variable, cyclical terms and bias terms (see text).

SKILL is the ratio of administrative, technical and clerical staff to total workers. UNION is the proportion of full-time manual males covered by collective agreements. $R \& D 1$ is the ratio of the stock of industryfunded Business Enterprise spending on $R \& D(B E R D)$ to the physical capital stock. Trend=normal trend, $\operatorname{Tr} 73 q 1=$ normal trend starting in $1973 q 1$ and 0 before, $\operatorname{Tr} 79 q 3=$ normal trend starting in $1979 q 3$ and 0 before, Tr80q4=normal trend starting in 1980q4 and 0 before. Tren=normal trend starting in 1990q3, and constant after 1992q2, 0 before 1990q3.

ADF $(N) \quad$ Augmented Dickey-Fuller test with N lags, MacKinnon (1991).

AR (M-N,T-K-M) F-test for $N$-th to $M$-th order residual autocorrelation in a model with $K$ regressors and tobservations, Harvey (1989).

ARCH $(r, T-2 r-K) \quad F$-test for Autoregressive Conditional Heteroscedasticity of $r$-th order.

Normality (2) $\quad \chi^{2}$ test for Normality, Jarque and Bera (1980).

$H S$

F-test for heteroscedasticity, White (1980).

RESET (j,T-j-K) F-version of the RESET test for $j$ powers, Ramsey (1969). 
Taken as a whole, the thirteen regressions reported in tables 2 to 4 present a coherent picture, with robust estimates of the effect of R\&D on TFP even in the presence of a stochastic trend. In the following discussion, regression 1 is taken to represent the preferred model. The results of regression 1 in full are:

\section{Table 5}

Solved Static Long-Run Estimates of Regression 1

\begin{tabular}{llll}
\hline \hline lTFP $=$ & 1.245 & $+0.276 l$ skill & $-0.127 l$ UNION \\
& $(0.46)$ & $(0.12)$ & $(0.06)$ \\
& $+0.288 l R \& D 1$ & +0.0043 Trend & \\
$(0.11)$ & $(0.0006)$ & \\
& $+0.004 P C$ & $-0.200 P R$ & $+0.217 P W$ \\
$(0.001)$ & $(0.043)$ & $(0.039)$ \\
$-0.0188 O V E R$ & $+0.158 N O R M A L$ & \\
$(0.003)$ & $(0.0446)$ & \\
& + Seasonals & & \\
& & & \\
& $R^{2}=0.9979$ & s.e. $=0.0112$ & \\
ADF $=-4.8[P=0.01]$ & & \\
\hline \hline
\end{tabular}

Source: Regression 1 in table 2.

Notes: Heteroscedasticity-Consistent standard errors in normal parentheses.

Based on the results in table 5, figure 4 decomposes UK TFP growth into three components - the effect of the bias terms $\{p c, p r$, and $p w\}$, the effect of the cyclical terms $\{$ over and normal $\}$, and the effect of the trend terms $\{l s k i l l$, lunion, $l R \& D 1$, and Trend $\}$ There is a marked slowdown in the growth of trend TFP in the mid 1970s, as discussed below.

Table 6 decomposes TFP growth in a variety of ways for four separate time periods and for the entire sample. The first, 1960q1 to 1973q1, covers the period until the first oil shock. The second, 1973q1 to 1979q2, covers the peak to peak business cycle of the 1970s. The third, 1979q2 to 1990q2, covers the peak to peak business cycle of the 1980s. The fourth, 1990q2 to 1995q3, covers the end of the whole data set. Finally, 1960q1 to 1995q3 covers the entire data set. 


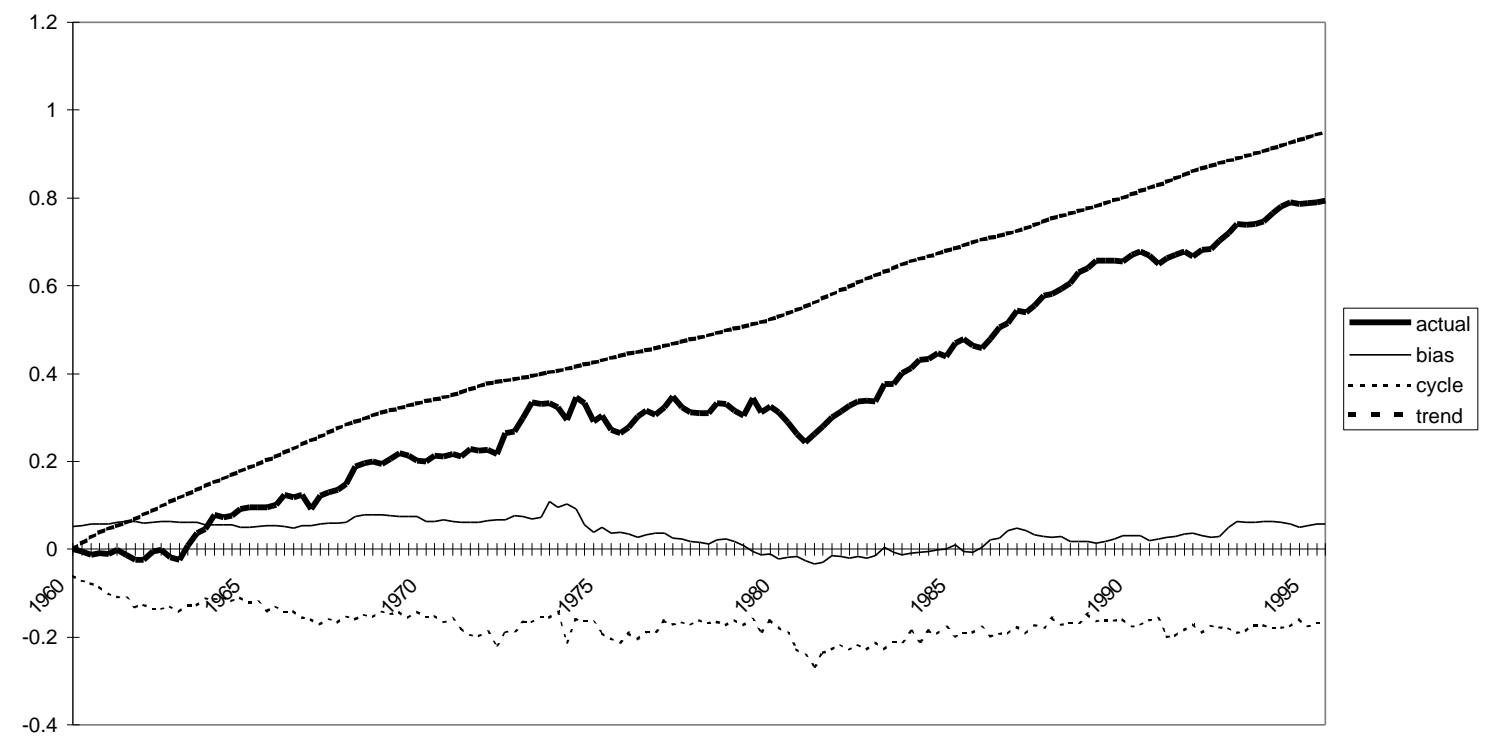

The first section of table 6 decomposes labour productivity growth (Y/L) into TFP growth and growth in the capital to labour ratio $(\mathrm{K} / \mathrm{L})$. Of the five time periods, the 1970s business cycle looks very distinctive, with low TFP growth and low labour productivity growth, although capital deepening appears to carry on at much the same rate as in the other periods. The rate of TFP growth is slightly lower after 1990q2 than in the 1980s, suggesting a slowdown. However, this measure of TFP is unadjusted for the business cycle and other biases and so is not a good estimate of trend growth.

The second section of table 6 decomposes TFP growth into four components - the effects of biases, the business cycle, trends, and other components. The 'bias' represents the effect of the price bias terms discussed earlier - the proxy for price controls, the ratio of input prices to output prices, and the ratio of export prices to output prices. The 'cyclical' effects represent the effect of the overtime hours terms and normal hours terms. The 'trend' effects represent the effect of the base time trend, human capital, unionization, and the ratio of the stock of industry-funded BERD to physical capital. The 'other' effect consists of the residual and seasonal factors. Note that the cyclical effect of -0.81 per cent p.a. during the 1960s reflects the reduction in normal working hours, as estimated by the interaction between normal hours and overtime hours, normal. 
Percentage Change Per Annum

\begin{tabular}{|c|c|c|c|c|c|}
\hline & 1960q1-73q1 & $1973 q 1-79 q 2$ & $1979 q 2-90 q 2$ & 1990q2-95q3 & $1960 q 1-95 q 3$ \\
\hline \multicolumn{6}{|c|}{ Decomposition of Y/L } \\
\hline Y/L & $4.20 \%$ & $1.50 \%$ & $4.62 \%$ & $3.46 \%$ & $3.75 \%$ \\
\hline TFP & $2.58 \%$ & $0.15 \%$ & $3.03 \%$ & $2.20 \%$ & $2.23 \%$ \\
\hline $\mathbf{K} / \mathbf{L}$ & $1.62 \%$ & $1.35 \%$ & $1.59 \%$ & $1.26 \%$ & $1.51 \%$ \\
\hline \multicolumn{6}{|c|}{ Decomposition of TFP } \\
\hline TFP & $2.58 \%$ & $0.15 \%$ & $3.03 \%$ & $2.20 \%$ & $2.23 \%$ \\
\hline Biases & $0.12 \%$ & $-1.16 \%$ & $0.33 \%$ & $0.50 \%$ & $0.02 \%$ \\
\hline Cycle & $-0.81 \%$ & $0.11 \%$ & $-0.11 \%$ & $0.03 \%$ & $-0.31 \%$ \\
\hline Trends & $3.04 \%$ & $1.88 \%$ & $2.75 \%$ & $2.56 \%$ & $2.67 \%$ \\
\hline Other ${ }^{*}$ & $0.23 \%$ & $-0.67 \%$ & $-0.06 \%$ & $-0.88 \%$ & $-0.15 \%$ \\
\hline \multicolumn{6}{|c|}{ Decomposition of Trends } \\
\hline Trends & $3.04 \%$ & $1.88 \%$ & $2.75 \%$ & $2.56 \%$ & $2.67 \%$ \\
\hline SKILL & $0.52 \%$ & $0.34 \%$ & $0.29 \%$ & $0.22 \%$ & $0.37 \%$ \\
\hline UNION & $-0.11 \%$ & $-0.06 \%$ & $0.25 \%$ & $0.06 \%$ & $0.04 \%$ \\
\hline $\mathrm{R} \& \mathrm{D}$ & $0.92 \%$ & $-0.11 \%$ & $0.50 \%$ & $0.55 \%$ & $0.55 \%$ \\
\hline Other $^{+}$ & $1.72 \%$ & $1.72 \%$ & $1.72 \%$ & $1.72 \%$ & $1.72 \%$ \\
\hline \multicolumn{6}{|c|}{$\begin{array}{l}\text { Notes: } \\
\text { May not sum exactly due to rounding. These estimates are based on the parameters in regression (1). } \\
\text { SKILL is the ratio of administrative, technical and clerical staff to total workers. UNION is the proportion } \\
\text { of full-time manual males covered by collective agreements. R\&D is the ratio of the stock of industry- } \\
\text { funded Business Enterprise spending on } R \& D(B E R D) \text { to the physical capital stock. \% change in labour } \\
\text { productivity = \% change in TFP }+\% \text { change in the contribution of the capital to labour ratio. } \\
{ }^{*} \text { Includes the residual plus seasonal factors. } \\
{ }^{+} \text {This is the effect of the base trend. }\end{array}$} \\
\hline
\end{tabular}

The rate of growth of TFP ranges from 0.15 per cent p.a. in the 1970 s to 3.03 per cent p.a. in the 1980s, and averages 2.23 per cent over the whole period. However, the decomposition makes clear that these very different performances have different sources, with the trend effect (that is, the effect of $R \& D$, unionization, human capital, and the time trends) being fairly stable, except for a slowdown in the 1970s. Even so, the slowdown in trend growth is much less marked than the slowdown in measured TFP growth.

What then explains the growth slowdown in the 1970s? Of the 2.43 percentage point fall in the annual rate of growth of measured TFP, the bias terms account for 1.28 percentage points, the business cycle accounts for -0.92 percentage points, the trend fall accounts for 1.16 percentage points, and other effects account for 0.90 percentage points. The effect of the bias terms in exaggerating the fall in measured TFP growth is considerable, which is not 
surprising since the rise in input prices between $1973 \mathrm{q} 1$ and $1974 \mathrm{q} 2$ alone reduces measured TFP by around 7.4 per cent. It is also interesting that the estimated trend in TFP is only slightly lower in the 1990s than the 1980s. Similarly, much of the growth upturn in the $1980 \mathrm{~s}$ is attributable to measurement bias. Of the 2.88 percentage point speedup, over half (1.49 percentage points) is due to the unwinding of the measurement bias effects. Another 0.22 percentage points are due to differences in cyclical utilization, while 0.87 percentage points are due to the trend effects.

The third section of table 6 decomposes the trend in TFP into four components - the effect of human capital, unionization, $\mathrm{R} \& \mathrm{D}$, and the time trend effect. Much of the 1.16 percentage point trend slowdown in the 1970 s is due to a 1.03 percentage point slowdown in the rate of growth of the R\&D capital stock, along with a 0.18 percentage point slowdown in the human capital effect. However, this is partly offset by a 0.05 percentage point increase from de-unionization. The effect of R\&D stock growth rises in the 1980s, but does not return to its 1960 s levels, but this is compensated by strong de-unionization effects in the 1980s. The effect of human capital falls throughout the period, which may occur because the measure of human capital used is the ratio of administrative, technical, and clerical staff to total worker. This may be a proxy for bureaucracy just as much as it is a proxy for human capital. Note from comparison of regression 1 and regression 2 that the estimated effects of unionization and $R \& D$ are little different when human capital is excluded from the estimation, while the estimated time trend is lower.

Recall that there is little to choose between regression 1 and regression 10 in terms of fit, although the forgoing analysis has used the specification from regression 1 on the grounds that it contains economic variables, rather than time trends necessarily fitted post-hoc. In fact, the estimated time trend effects from regression 10 are similar to the estimates from regression 1, although the growth slowdown in the $1970 \mathrm{~s}$ is rather stronger (1.63 percentage points compared with 1.16 percentage points). Note that the bias and cyclical effects estimated in regression 10 (not reported) are very similar to those in regression 1.

\section{Conclusion}

This paper has constructed a quarterly model of UK total factor productivity from 1960 to 1995, following the suggestions of Jones and Williams (1998) and Barro (1999) that such 
regressions can be seen as variants of simple endogenous growth models. The paper helps to answer two sets of questions.

First, what are the effects of R\&D capital, human capital, and unionization on productivity growth in UK manufacturing? The paper finds an elasticity of output with respect to industry-funded Business Enterprise R\&D capital of between 0.2 and 0.3 , suggesting that there are large and significant returns to that part of $R \& D$ funded and performed by business itself. These estimates are rather larger than traditionally found (see Griliches, 1992) but are consistent with the estimates of Coe and Helpman (1995). Evidence was found of lower returns to government-funded $R \& D$ and there was no evidence of significant returns to payments for technological royalties. In the case of governmentfunded R\&D this may be because it has less market-orientated goals, which while yielding a social return, do not yield increases in measured value-added; or because the time lags involved are longer than for industry-funded $R \& D$. In the case of technological royalties this may be because they are a poor measure of the extent to which UK firms import foreign technologies (partly because they reflect the accounting and tax procedures of multinational corporations) and because adoption requires substantial domestic research efforts in any case. Unfortunately, no other measure of technology imports or adoption is available for the period studied in this paper.

Decreasing unionization was found to have raised UK productivity and this accounted for a substantial part of the upturn in trend growth in the 1980s. The measure of unionization used is the percentage of full-time manual males covered by collective bargaining. Gregg, Machin, and Metcalf (1993) among others have also found evidence that the reduction in unionization in the 1980s was associated with increased productivity, presumably through a 'right to manage' mechanism. This paper is unable to test Gregg, Machin, and Metcalf's ancillary hypothesis that the most heavily unionised industries had the highest productivity improvements in the early 1980s. Turning to human capital, although the measure used may well be a proxy for bureaucracy rather than human capital, the ratio of administrative, technical and clerical workers to total workers was found to have had a positive and generally significant effect on TFP. In the context of this paper, increases in human capital lead to increases in TFP. Note, however, that the measure of human capital is bounded and cannot rise above unity (when all workers are skilled). If that point were reached, then $\mathrm{R} \& \mathrm{D}$ would remain the only source of long-run growth. 
Second, what were the causes of the growth slowdown in the 1970s, and why did growth speed up in the 1980s? Table 6 presents the main results. The single-deflation bias is found to have played a significant role in the slowdown (although not as strong an effect as estimated by Stoneman and Francis, 1994). When input prices rose in 1973 and 1974, there was a downward bias to measured value-added. To some extent this bias unwound in the 1980s, leading to an upward bias in measured value-added growth. The trend rate of growth fell by around a third in the 1970s, and much of that fall can be attributed to a slowdown in the rate of growth of R\&D capital. Again, this reversed to some extent in the 1980s, leading to higher trend growth, helped by de-unionization.

This paper has paid careful attention to the role of measurement biases. As discussed above, it finds that around a half (1.28 percentage points of a 2.43 percentage point fall) of the growth slowdown in the 1970s can be attributed to measurement bias. Similarly, around a half (1.49 percentage points of a 2.88 percentage point rise) of the growth upturn in the 1980s can be attributed to measurement bias. The magnitude of these effects, coupled with the potential size of cyclical effects on TFP, suggests that the trend rate of TFP growth will always be difficult to infer from the raw data.

Even so, after correcting for biases and the cycle, the trend rate of TFP growth does appear to have been significantly higher in the 1980s than in the 1970s and does not appear to have fallen significantly in the 1990s. Any claim that the 1980s featured a UK manufacturing productivity miracle is dramatically weakened, however, when one considers that the estimated trend rate of growth in the 1980s is 2.75 per cent p.a., compared with 3.04 per cent p.a. in the 1960 s. 


\section{Data Appendix}

Real Output: taken from the Index of Production - index of manufacturing output.

Producer Prices: Producer Prices (input \& output) indices supplied by the Office of National Statistics (ONS).

Labour Input: Total employment is from the Census of Production. From this, the number of R\&D workers was subtracted. Normal and overtime hours worked per week (full-time males) are taken from the New Earnings Survey and from information supplied by the Employment Department. Weeks worked are taken from Employment Gazette. Hours worked per year in manufacturing is the result of multiplying employees by hours by weeks worked.

Capital Input: Data for manufacturing were supplied directly by the ONS. An estimate of capital equipment used for R\&D purposes was subtracted.

Total Factor Productivity: Is calculated from data on real output, labour input and capital input as above. The measure of TFP is based on the Divisia methodology, and takes the exponents of labour and capital at time $t$ to be equal to the average of their shares in output at time $t$ and time $t-1$.

Capacity Utilisation (cap): The CBI Industrial Trends Survey asks the following question: 'Is your present level of output below capacity (i.e. are you working below a satisfactory full rate of operation)?' These data were used to compile a capacity utilisation index, following Muellbauer (1991). Formally, cap $=\log [((\mathrm{cbi} / 100) /(1-(\mathrm{cbi} / 100))) * * 4]$, where $c b i$ is the percentage working below capacity.

Overtime hours (over) and the Normal hours and Overtime hours interaction (normal): The overtime hours measure is intended to correct for variations in labour utilization, while the normal hours and overtime hours interaction corrects for increases in overtime hours in the 1960s that were due to systematic decreases in normal hours and hence represented disguised wage increases. Formally, the inverse of overtime hours, overt, is defined as over $=($ normal hours worked $*$ total number of operatives)/(total number of overtime hours for operatives). The normal and overtime hours interaction, normal, is defined as normal $=($ normal hours index-90.4/100)*over. The normal hours index is equal to 100 in 1955q1, and takes the value 90.4 between 1968 and 1979. All these data are available in the Employment Gazette. See Muellbauer (1984) for details.

Constant prices Business Enterprise Research and Development (BERD): Data on Business Enterprise R\&D at current prices were taken from ONS (1995). Current price data were converted into constant prices using the Divisia price indices for UK BERD calculated in Cameron (1996). The flows of constant price BERD were converted into capital stocks using a 10 per cent per annum depreciation rate. The base value assumption commonly used in the literature (see Hall and Mairesse, 1995, for example) is $D_{t}=R t /\left(\gamma_{D}+\delta_{D}\right)$, where $D_{t}$ is the R\&D stock in the initial year, $R_{t}$ is R\&D spending in the initial year, $\gamma_{D}$ is the growth rate of $R \& D$ spending over some initial period, and $\delta_{D}$ is the depreciation rate of R\&D capital. For example if $\gamma_{D}$ is $10 \%$ per annum and $\delta_{D}$ is $10 \%$ per annum, then $R_{t}$ should be divided by 0.2 , so that $\mathrm{R} \& \mathrm{D}$ capital is five times the current level of spending. Obviously, the higher the growth rate and depreciation rate, the lower must be 
the current capital stock relative to current spending. The following variables were used: R\&D1 is the ratio of the stock of industry-funded Business Enterprise spending on R\&D (BERD) to the physical capital stock. R\&D2 is the ratio of the stock of total BERD to the physical capital stock. $R \& D 3$ is the ratio of the stock of technological royalties to the physical capital stock. R\&D4 is the stock of industry-funded BERD.

Technological Royalties: Data supplied by Alan Carter of the Department of Trade and Industry on payments for licenses for technology.

Ratio of skilled to total workers (SKILL): This is the ratio of administrative, technical and clerical staff to total workers available biannually and taken from the Employment Gazette.

Collective Agreement Coverage (UNION): Proportion of manual employees covered by collective bargaining agreements. Data for 1973, 1978 and 1985 are available in the New Earnings Survey. Changes in union density were used to make interpolations between those years. These data were supplied by Brian Bell. Union density data for before 1970 are from the Employment Gazette. 


\section{Appendix I: A VAR model of UK total factor productivity}

As a first step in the modelling procedure a vector autoregressive model using the Johansen (1988) procedure was estimated. For simplicity of estimation and interpretation, the vector of variables considered at this stage was restricted to $\{l t f p, l R \& D 1, l$ skill,lunion\}. In addition to the four stochastic variables, the system contained a constant, a trend, and a split time trend that starts in the first quarter of $1973(\operatorname{tr} 73 q 1){ }^{19}$

Next, the lag length for the vector autoregression was determined, starting with an initial lag length of four. However, simplification tests of the initial system lag length suggested that two lags sufficed, so this restriction was imposed (the likelihood-ratio test for this restriction has a test statistic of $F(32,517)=1.11$ $[\mathrm{P}=0.31])$. Table AI.1 reports the lag length tests and equation standard errors for the two lag model. The F-test for the hypothesis of an $i$-period lag ( $\mathrm{Fs}=\mathrm{i}$ ) is accepted for all the lags except the second lag of ltfp which is insignificant. Note that the estimated standard error of the ltfp equation is s.e. $=0.01473$.

Table AI.1

Lag lengths and equation standard errors for VAR model

\begin{tabular}{lllll}
\hline \hline Statistic & Ltfp & 1R\&D1 & lskill & lunion \\
\hline Fs $=1(4,129)$ & $20.2^{* *}$ & $499.2^{* *}$ & $166.9^{* *}$ & $288.0^{* *}$ \\
Fs $=2(4,129)$ & 1.5 & $110.5^{* *}$ & $28.6^{* *}$ & $59.3^{* *}$ \\
s.e. & 0.0147 & 0.0013 & 0.0020 & 0.0021 \\
\hline \hline
\end{tabular}

Table AI.2

Eigenvalues of $\Pi$

\begin{tabular}{llllll}
\hline \hline$v$ & $\lambda v$ & $-T \log (1-\mu)$ & $5 \%$ critical & $-\operatorname{Tlg}(1-\mu)$ & $5 \%$ critical \\
\hline 1 & 0.36 & $43.7^{* *}$ & 31.5 & $94.4^{* *}$ & 63.0 \\
2 & 0.03 & 22.8 & 25.5 & 41.2 & 42.4 \\
3 & 0.03 & 16.5 & 19.0 & 25.0 & 25.3 \\
4 & 0.01 & 11.5 & 12.2 & 11.5 & 12.2 \\
\hline \hline
\end{tabular}

Table AI.2 reports the eigenvalues $\{\lambda i\}$ and eigenvectors of the long-run matrix $\Pi=\alpha \beta^{\prime}$ for $T=1960(1)$ 1995(3). The null of no cointegrating vectors $(v=0)$ can be rejected at the $5 \%$ level in favour of one according to both tests $\zeta_{10}(v)=-T \Sigma_{1=v+1}^{N} \ln \left(1-\lambda_{i}\right)$ and $\zeta_{11}(v)=-T \ln \left(1-\lambda_{v}\right)$, but one cannot be rejected in favour of two. The first cointegration vector $\hat{\beta}$ normalized on ltfp is:

(AI.1)

$$
\text { ltfp }=0.28 \text { lbk } 1+0.13 \text { latc }-0.17 \text { lunion }+0.013 \text { trend }-0.005 \text { tr } 73 q 1
$$

Table AI.3

$\alpha^{\prime}$-vector

\begin{tabular}{lllll}
\hline \hline Variable & ltfp & 1R\&D1 & lskill & lunion \\
\hline Ltfp & -0.28 & -0.01 & -0.05 & 0.01 \\
\hline \hline
\end{tabular}

Table AI.3 reports the estimated $\alpha^{\prime}$ vector for equation (AI.1). The first element in $\alpha^{\prime}$ implies a feedback coefficient of -0.28 , while the other elements are sufficiently small to suggest that there is little feedback from those equations, and hence that weak exogeneity holds. 


\section{References}

Acemoglu, D. and Scott, A. (1994) 'Asymmetries in the Cyclical Behaviour of UK Labour Markets', Economic Journal, vol. 104, pp. 1303-1323.

Aghion, P. and Howitt, P. (1992) 'A Model of Growth through Creative Destruction', Econometrica, vol. 60, pp. 323-51.

Barro, R. (1991) 'Economic Growth in a Cross-Section of Countries', Quarterly Journal of Economics, vol. 106, pp. 407-44.

Barro, R. (1999) 'Notes on Growth Accounting', Journal of Economic Growth, 4, pp. 119-138.

Bartelsman, E., van Leeuwen, G., and Nieuwenhuijsen, H. (1996) 'Adoption of Advanced Manufacturing Technology and Firm Performance in the Netherlands', Economics of Innovation and New Technology, 6, pp. 291-312.

Bean, C. and Crafts, N. (1996) 'British Economic Growth since 1945: relative economic decline ... and renaissance?' in Crafts, N. and Toniolo, G. (eds.) Economic Growth in Europe since 1945 (CUP:Cambridge).

Benhabib, J. and Spiegel, M. (1994) 'The role of Human Capital in Economic Development: Evidence from Aggregate Cross-Country Data', Journal of Monetary Economics, vol. 34, pp. 143-173.

Bruno, M. and Sachs, J. (1985) The Economics of Worldwide Stagflation (Oxford:Blackwell).

Cameron, G. (1996) 'On the measurement of real R\&D: Divisia Price Indices for UK Business Enterprise R\&D', Research Evaluation, vol. 6, pp. 215-219.

Cameron, G. and Muellbauer, J. (1996) 'Knowledge, Increasing Returns, and the UK Production Function', in Mayes, D. ed. Sources of Productivity Growth (Cambridge:Cambridge University Press), pp. 120-140.

Cameron, G., Proudman, J. and Redding, S. (1998) 'Deconstructing Growth in UK Manufacturing', chapter 4 in Proudman, J. and Redding, S. eds. Openness and Growth (London: Bank of England), pp. 138172.

Cameron, G., Proudman, J. and Redding, S. (1999) 'Productivity Growth, Convergence and Trade in a Panel of Manufacturing Industries', Centre for Economic Performance Discussion Paper no. 428.

Chow, G. (1960) 'Tests of Equality between sets of coefficients in two linear regressions', Econometrica, vol. 28, pp. 591-605.

Coe, D. and Helpman, E. (1995) 'International R\&D Spillovers', European Economic Review, vol. 39, pp. 859-888.

Darby, M. (1984) 'The U.S. Productivity Slowdown: A Case of Statistical Myopia', American Economic Review, vol. 74, pp. 301-22.

Dasgupta, P. and Maskin, E. (1987) 'The Simple Economics of Research Portfolios', The Economic Journal, vol. 97, pp. 581-95.

Denison, E. (1974) Accounting for US Economic Growth, 1929 to 1969 (Washington, DC:Brookings Institution).

Denny, K. and Nickell, S. (1991) 'Unions and Investment in British Manufacturing Industry', British Journal of Industrial Relations, vol. 29, pp. 113-21.

Eicher, T. (1999) 'Trade, Development and Converging Growth Rates: Dynamic Gains from Trade Reconsidered', Journal of International Economics, 48, pp. 179-198. 
Engle, R. (1982) 'Autoregressive Conditional Heteroscedasticity, with Estimates of the Variance of United Kingdom Inflations’, Econometrica, vol. 50, pp. 987-1008.

Gollop, F. (1987) 'Modelling Aggregate Productivity Growth: The Importance of Intersectoral Transfer Prices and International Trade', Review of Income and Wealth, vol. 33, pp. 211-227.

Gregg, P., Machin, S. and Metcalf, D. (1993) 'Signals and Cycles? Productivity Growth and Changes in Union Status in British Companies, 1984-9’, Economic Journal, vol. 103, pp. 894-907.

Griliches, Z. (1980) 'Returns to R\&D Expenditures in the Private Sector', in Kendrick, K.W. and Vaccara, B. (eds.) New Developments in Productivity Measurement (Chicago:University Press).

Griliches, Z. (1992) 'The Search for R\&D Spillovers', Scandinavian Journal of Economics, vol. 94, pp. S29-47.

Griliches, Z. (1994) 'Productivity, R\&D and the Data Constraint,' American Economic Review, 1994, 84(1), pp. 1-23.

Grossman, G. and Helpman, E. (1991) Innovation and Growth in the Global Economy (Cambridge:MIT Press).

Grout, P. (1984) 'Investment and Wages in the Absence of Binding Contracts - a Nash Bargaining Approach', Econometrica, vol. 52, pp. 449-460.

Hall, B. and Mairesse, J. (1995) 'Exploring the Relationship between R\&D and Productivity in French Manufacturing Firms', Journal of Econometrics, vol. 65, pp. 263-94.

Hall, R. (1990) 'Invariance Properties of Solow's Productivity Residual', in Diamond, P. ed. Growth/Productivity/Unemployment: Essays to Celebrate Bob Solow's Birthday (Cambridge: MIT Press), pp. 71-112.

Hamilton, J. and Monteagudo, J. (1998) 'The Augmented Solow Model and the Productivity Slowdown', Journal of Monetary Economics, 42, pp. 495-509.

Harvey, A. (1989) Forecasting, Structural Time Series Models and the Kalman Filter (CUP:Cambridge).

Haskel, J. (1999) 'Small Firms, Contracting-Out, Computers and Wage Inequality: Evidence from UK Manufacturing', Economica, 66, pp. 1-22.

Hendry, D. (1995) Dynamic Econometrics (Oxford:Oxford University Press).

Hendry, D. and Doornik, J. (1996) Empirical Econometric Modelling Using PCGive for Windows (London: International Thomson Publishing).

Jarque, C. and Bera, A. (1980) 'Efficient Tests for Normality, Homoscedasticity and Serial Independence of Regression Residuals', Economics Letters, vol. 6, pp. 255-9.

Jenkins, H. (1995) 'Education and Production in the United Kingdom', Nuffield College working paper no. 101 (Nuffield College, Oxford).

Johansen, S. (1988) 'Statistical Analysis of Cointegration Vectors', Journal of Economic Dynamics and Control, vol. 12, pp. 231-54.

Jones, C. and Williams, J. (1998) 'Measuring the Social Return to R\&D', Quarterly Journal of Economics, 113, pp. 1119-1135.

Katz, M. and Shapiro, C. (1994) 'Systems Competition and Network Effects', Journal of Economic Perspectives, vol. 8, no. 2, pp. 93-115. 
Krugman, P. (1994) 'Past and Prospective Causes of High Unemployment' in Reducing unemployment: Current issues and policy options, (FRB Kansas:Kansas City, MO).

Ledic, M. and Silbertson, A. (1986) 'The Technological Balance of Payments in Perspective' in Hall, P. ed. Technology, Innovation and Economic Policy (Oxford:Philip Allan).

Lucas, R. (1988) 'On the Mechanics of Economic Development', Journal of Monetary Economics, vol. 22, pp. 3-42.

Machin, S. (1994) 'Changes in the Relative Demand for Skills in the UK Labour Market', CEPR Discussion Paper, No. 952.

Machin, S. and Wadhwani, S. (1991) 'The effects of Unions on Organisational Change and Employment', Economic Journal, vol. 101, pp. 835-54.

MacKinnon, J. (1991) 'Critical Values for Cointegration Tests' in Engle, R. and Granger, C. eds. LongRun Economic Relationships (Oxford:OUP).

Maddison, A. (1994) 'Explaining the Economic Performance of Nations', in Baumol, W., Nelson, R. and Wolff, E. Convergence of Productivity: Cross-National Studies and Historical Evidence (Oxford: OUP).

Mansfield, E. (1985) 'How Rapidly Does Industrial Technology Leak Out?', Journal of Industrial Economics, vol. 34, no. 2, pp. 217-223.

Martins, J., Scarpetta, S. and Pilat, D. (1996) 'Mark-up Pricing, Market Structure and the Business Cycle', OECD Economic Studies, no. 27, pp. 71-106.

Mendis, L. and Muellbauer, J. (1984) 'British Manufacturing Productivity 1955-1983: Measurement Problems, Oil Shocks, and Thatcher Effects', CEPR Discussion paper no. 32.

Muellbauer, J. (1984) 'Aggregate Production Functions and Productivity Measurement: A New Look' CEPR Discussion Paper no. 34.

Muellbauer, J. (1991) 'Productivity and Competitiveness', Oxford Review of Economic Policy, vol. 7, no. 3.

Nickell, S. and Bell, B. (1996) 'Changes in the Distribution of Wages and Unemployment in OECD Countries', American Economic Review, vol. 86, pp. 302-308.

O'Mahony, M. and Wagner, K. (1996) 'Changing Fortunes: an industry study of British and German productivity growth over three decades', in Mayes, D. (eds.) Sources of Productivity Growth in the 1980s (Cambridge:Cambridge University Press)

Oulton, N. and O'Mahony, M. (1994) Productivity and Growth: A study of British Industry, 1954-1986, (Cambridge: CUP).

Purcell, J. (1991) 'The rediscovery of the management prerogative: the management of labour relations in the 1980s', Oxford Review of Economic Policy, vol. 7, pp. 33-43.

Ramsey, J. (1969) 'Tests for Specification Errors in Classical Linear Least Squares Regression Analysis', Journal of the Royal Statistical Society, Series B, vol. 31, pp. 350-71.

Roeger, W. (1995) 'Can Imperfect Competition Explain the Differences Between Primal and Dual Productivity Measures? Estimates for US Manufacturing', Journal of Political Economy, vol. 103, pp. 316330.

Romer, P. (1990) 'Endogenous Technological Change', Journal of Political Economy vol. 98, pp. S71S102.

Schankerman, M. (1981) 'The Effects of Double-Counting and Expensing on the Measured Returns to R\&D', Review of Economics and Statistics, vol. 63, pp. 454-459. 
Sensier, M. (1998) 'Inventories and Asymmetric Business Cycle Fluctuations in the UK', IES Discussion Paper no. 192 (Institute of Economics \& Statistics, University of Oxford:mimeo).

Sichel, D. (1997) 'The Productivity Slowdown: Is a Growing Unmeasurable Sector the Culprit?', Review of Economics and Statistics, 79, pp. 367-70.

Stoneman, P. and Francis, N. (1994) 'Double Deflation and the Measurement of Output and Productivity in UK Manufacturing, 1979-1989’, International Journal of the Economics of Business, vol. 1, pp. 423-437.

Ulph, A. and Ulph, D. (1994) 'Labour Markets and Innovation: Ex-Post Bargaining', European Economic Review, vol. 38, pp. 195-210.

Verspagen, B. (1995) 'R\&D and Productivity: A Broad Cross-Section, Cross-Country Look', Journal of Productivity Analysis, vol. 6, pp. 117-135.

White, H. (1980) 'A heteroscedasticity-consistent covariance matrix estimator and a direct test for heteroscedasticity', Econometrica, vol. 48, pp. 817-838.

Wolff, E. (1996) 'The Productivity Slowdown: The Culprit at Last? Follow-Up on Hulten and Wolff', American Economic Review, 86, pp. 1239-1252.

Wood, A. (1994) North-South trade, employment, and inequality: Changing fortunes in a skill driven world (Clarendon: Oxford). 
${ }^{1}$ Mansfield (1985) shows that knowledge of innovations leaks between firms relatively quickly.

${ }^{2}$ Griliches (1992) argues that the extent to which this effect exists and can be measured is dependent upon the competitive structure of the innovating and downstream industries, and whether the price indices used in the national accounts allow for 'quality' changes.

${ }^{3}$ Aghion and Howitt (1992) present a model of growth through creative destruction.

${ }^{4}$ Katz and Shapiro (1994) argue that innovations are complements, while Dasgupta and Maskin (1987) argue that they are substitutes.

5 Another potentially important source of ideas is from abroad, see Grossman and Helpman (1991) and Eicher (1999) for example. Unfortunately, the aggregate time-series approach adopted here is not ideal for such an exercise since the empirical effect of openness on growth is probably best explored using crosssection or panel data, see Cameron, Proudman and Redding (1999) for example. This paper does use a measure of foreign technology adoption - payments for technological royalties. However, see Ledic and Silbertson (1986) for some discussion of the problems with such data. Experiments were conducted with a trade-weighted foreign R\&D stock variable similar to that of Coe and Helpman (1995) but found no significant effect.

${ }^{6}$ Over the period 1976-1991, where data on qualification are available, the correlation coefficient between the proportion of non-manual to total workers in UK manufacturing and the proportion with high levels of qualifications is 0.91 , and with medium levels of qualifications 0.76 .

7 Other possible measures of union power are union density data and union mark-up (union wage differentials) data. Collective bargaining data is used because it is a better indicator of the influence of unions in the sector than union density. Union mark-up data would be preferable, but are not available over the entire period studied in this paper. Collective bargaining data were used in the analysis of the effect of unionisation on investment by Denny and Nickell (1991).

${ }^{8}$ This is the proportion of full-time adult manual males covered by some form of collective bargaining agreement multiplied by the share of male manual workers in total employment. Data for 1973, 1978 and 1985 are available in the New Earnings Survey. Data on changes in union density were used to make interpolations for other years. I am grateful to Brian Bell for supplying these data and to Stephen Nickell for helpful discussions on their use.

9 Note that TFP as defined in the paper is not corrected for the possibility of market power as discussed by Hall (1990) and Roeger (1995). Recent estimates of mark-ups in UK manufacturing, such as Martins et al. (1996) have found mark-ups of around 10 per cent. Experiments were conducted with a TFP measure corrected for such a mark-up but they found no significant differences in the results.

${ }^{10}$ A related problem arises because the official producer price indices for output are calculated on a net sector basis (that is, refer to transactions with other sectors, but not within manufacturing), while measures of manufacturing output include transactions within manufacturing (are on a gross sector basis).

${ }^{11}$ Around 30 per cent of manufacturing sales are exports, though the share tends to be higher in industries where the data source is primarily sales (Mendis and Muellbauer, 1984, pp. 11). When the domestic price indices diverge from unobserved export prices, the 'domestic prices bias' arises. Stoneman and Francis (1994) also note this problem.

${ }^{12}$ Mendis and Muellbauer (1984) argue that this list price bias is likely to be correlated with the ratio of foreign to domestic prices, and also with the ratio of input to output prices. The first effect is because the reduced competitive pressure implicit in a fall in the value of sterling (and hence a rise in the ratio of foreign to domestic prices) is likely to reduce discounts. The second effect is because list prices are likely to respond more slowly than transactions prices to increases in the prices of raw materials.

${ }^{13}$ The index of production of manufacturing output, which is published by the Office of National Statistics, uses value-added to weight real gross output changes for individual industries, which are then aggregated up to the level of manufacturing as a whole.

${ }^{14}$ See Gollop (1987) for a discussion of how trade in foreign-produced intermediate inputs might lead to biases in the measurement of value-added. Since our measure of output is closer to being a gross output measure, it is likely that such biases are small and will be captured by the import price ratio term.

${ }^{15}$ See Schankerman (1981) and later in the text for discussion of the double-counting issue.

16 This rise and fall is also reflected in the raw union density data.

${ }^{17}$ All the single-equation modelling was conducted using the PCGive package of Hendry and Doornik (1996).

18 See Verspagan (1995) for similar evidence that double-counting does not lead to significant biases, and Hall and Mairesse (1995) for a contrary view. 
${ }^{19}$ Hendry (1995, chapter 15) discusses the econometrics of including dummy variables in VAR models. The constant is entered unrestrictedly, while the time trends are assumed exogenous so as to preclude the existence of quadratic trends in the levels of the variables. 